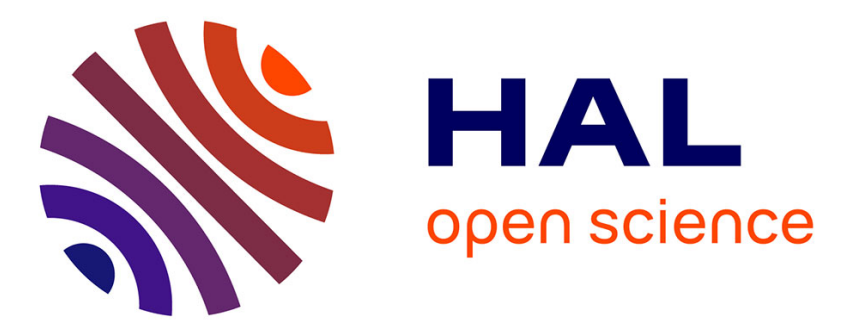

\title{
Clinical review of eight patients with acute respiratory distress syndrome due to pulmonary tuberculosis
}

P Befort, Philippe Corne, Sylvain Godreuil, Boris Jung, Olivier Jonquet

\section{To cite this version:}

P Befort, Philippe Corne, Sylvain Godreuil, Boris Jung, Olivier Jonquet. Clinical review of eight patients with acute respiratory distress syndrome due to pulmonary tuberculosis. Scandinavian Journal of Infectious Diseases, 2012, 10.3109/00365548.2011.611170 . hal-02549467

\section{HAL Id: hal-02549467 \\ https://hal.umontpellier.fr/hal-02549467}

Submitted on 21 Apr 2020

HAL is a multi-disciplinary open access archive for the deposit and dissemination of scientific research documents, whether they are published or not. The documents may come from teaching and research institutions in France or abroad, or from public or private research centers.
L'archive ouverte pluridisciplinaire HAL, est destinée au dépôt et à la diffusion de documents scientifiques de niveau recherche, publiés ou non, émanant des établissements d'enseignement et de recherche français ou étrangers, des laboratoires publics ou privés. 


\title{
Clinical review of eight patients with acute respiratory distress syndrome due to pulmonary tuberculosis
}

\author{
PATRICE BEFORT ${ }^{1}$, PHILIPPE CORNE ${ }^{1}$, SYLVAIN GODREUIL ${ }^{2}$, BORIS JUNG $^{3}$ \& \\ OLIVIER JONQUET ${ }^{1}$
}

From the ${ }^{1}$ Service de Réanimation Médicale Assistance Respiratoire, Hôpital Gui de Chauliac, ${ }^{2}$ Laboratoire de Bactériologie, Hôpital Arnaud deVilleneuve, and ${ }^{3}$ Service d'Anesthesie-Réanimation B, Hôpital Saint-Eloi, Centre Hospitalier Universitaire de Montpellier, Montpellier, France

\begin{abstract}
Pulmonary tuberculosis can lead to acute respiratory distress syndrome (ARDS) even in the absence of superinfection, and this condition requires mechanical ventilation. We describe herein the characteristics and outcomes of 8 patients with this association hospitalized in a French teaching hospital between 1997 and 2006.
\end{abstract}

Keywords: Mycobacterium tuberculosis, ARDS, multiple organ failure, ICU, nosocomial pneumonia

\section{Introduction}

Tuberculosis (TB) is an unusual cause of acute respiratory distress syndrome (ARDS) in the intensive care unit (ICU) [1]. The mortality rate in these patients is higher than in other causes of ARDS [2,3]. Only a few studies have reported the association of ARDS with TB $[4,5]$.

The goal of this study was to describe the characteristics and outcomes of TB with ARDS in a French teaching hospital.

\section{Patients and methods}

A retrospective study was performed in 5 ICUs of the university hospital in Montpellier, France, between December 1997 and December 2006. Patients were identified by a cross-search of the Medical Information Department database (patients hospitalized in the ICU with a diagnosis of TB and/ or ARDS) and the Mycobacteriology Department database (isolation of Mycobacterium tuberculosis). All adult patients with documented pulmonary TB and ARDS hospitalized in the ICU were included.
Pulmonary TB was defined by the isolation of $\mathrm{M}$. tuberculosis in bacterial culture from bronchial aspirates or bronchoalveolar lavage fluid or pleural effusion. ARDS was defined according to the American-European Conference criteria: $\mathrm{PaO}_{2} / \mathrm{FiO}_{2}$ ratio of $\leq 200$, bilateral infiltrates on chest radiography, and a pulmonary artery wedge pressure of $<15$ $\mathrm{mmHg}$ or no clinical evidence of heart failure [6].

Nosocomial pneumonia was defined according to the American Society guidelines as pneumonia occurring more than $48 \mathrm{~h}$ after hospital admission, and was detected by weekly surveillance tracheal aspirates.

The following data were obtained from medical records: demographic characteristics, co-morbidities, time from symptom onset to ICU admission, reasons for admission, simplified acute physiology score (SAPS) II and sepsis-related organ failure acute (SOFA) score, laboratory tests including HIV ELISA test, pulmonary investigation methods, treatments, delays between onset of symptoms and diagnosis or anti-tuberculous treatment, ICU mortality, cause of death, and ICU length of stay.

Chest radiographic patterns were interpreted by a trained radiologist, and reanalysis of the images was 
done at the time of data collection by an intensivist. Miliary TB was defined in the presence of pulmonary micronodules on chest radiographs. Drug resistance was defined by phenotypic proportional methods and multidrug resistance was defined as resistance to at least isoniazid and rifampicin [7].

Results are expressed as median values and interquartile range or percentages. The statistical analyses were performed using STAT-VIEW II (Abacus Concepts Inc, Berkeley, CA, USA). We performed a descriptive analysis by computing the frequencies and the percentages for categorical data, and the means, standard deviations, quartiles, and extreme values for continuous data.

\section{Results}

Eight patients with pulmonary TB and ARDS were identified over a 9-y period. Clinical and biological characteristics are summarized in Table I. The median age was 55.5 (interquartile range (IQR) 30-70) y. All patients were HIV-seronegative. Causes of hospitalization in the ICU were acute respiratory failure $(n=7)$ and digestive perforation $(n=1)$. Mycobacterium tuberculosis was isolated in bronchoalveolar lavage $(n=4)$, in tracheal aspirates $(n=3)$, and in pleural effusion $(n=1)$. Pulmonary samples at admission excluded superinfection in all cases. In 1 patient, M. tuberculosis was isolated in pulmonary and in

Table I. Patient clinical and biochemical characteristics on admission to the ICU.

\begin{tabular}{lc}
\hline Parameters & Results $^{\mathrm{a}}$ \\
\hline Age $(\mathrm{y})$ & $55.5(30-70)$ \\
Male/female ratio & $6 / 2$ \\
SOFA score & $6.5(4-9)$ \\
SAPS2 & \\
Thoracic radiography findings & 5 \\
Bilateral infiltrates $(n)$ & 2 \\
Miliary pattern $(n)$ & 2 \\
Cavitation $(n)$ & 1 \\
Pleural effusion $(n)$ & \\
Biochemistry on admission & $53.5(27-102)$ \\
Creatinine $(\mu \mathrm{mol} / 1)$ & $253(139-607)$ \\
Platelets $\left(\times 10^{9} / 1\right)$ & $189(27-255)$ \\
CRP $(\mathrm{mg} / \mathrm{l})$ & $9(8-33)$ \\
Bilirubin $(\mu \mathrm{mol} / \mathrm{l})$ & $23(8-27)$ \\
Albumin $(\mathrm{g} / \mathrm{l})$ & \\
Co-morbidities & 1 \\
COPD $(n)$ & 0 \\
Diabetes $(n)$ & 1 \\
Coronary artery disease $(n)$ & \\
\hline
\end{tabular}

ICU, intensive care unit; SOFA, sepsis-related organ failure assessment; SAPS, simplified acute physiology score; CRP, C-reactive protein; COPD, chronic obstructive pulmonary disease.

${ }^{\text {a }}$ Results are presented as median (interquartile range) unless stated otherwise. peritoneal samples. The diagnosis of TB was made in the ICU for 7 patients and before ICU admission for 1. The median delay between onset of symptoms and diagnosis was 43 (IQR 12-121) days.

All patients were mechanically ventilated; 6 were ventilated on admission and all were ventilated within the first $72 \mathrm{~h}$. No patients received non-invasive ventilation before mechanical ventilation. The median $\mathrm{PaO}_{2} / \mathrm{FiO}_{2}$ ratio on day 1 of ARDS was 93.5 (IQR 62-220). The duration of mechanical ventilation was a median 12 (IQR 1-73) days. Others ARDS therapeutics used were: intravenous corticosteroids $(n=2)$, procubitus ventilation $(n=2)$, neuromuscular blocking agents $(n=5)$, and inhaled nitric oxide $(n=3)$. During hospitalization 7 patients required vasopressors for a median 5.5 (IQR 1-56) days; 1 patient required inotropic agents; haemodiafiltration therapy was performed in 3 patients. A septic shock haemodynamic profile (including low systemic vascular resistance) was noted in 3 cases in the absence of other co-infections (haemodynamic monitoring by Swan-Ganz catheterization or PICCO system), and required vasopressor use.

All isolates of $M$. tuberculosis were susceptible to first-line anti-tuberculous drugs. Anti-tuberculosis therapy (ATT) including $3(n=2)$ or $4(n=6)$ firstline anti-tuberculous drugs was started in the ICU for 7 patients. One patient received ATT before ICU admission. The time between ICU admission and the start of ATT was a median 3 (IQR 2-11) days. ATT was administrated intravenously for 6 patients (ethambutol, isoniazid, rifampicin) and enterally via a nasogastric tube for the other 2 patients.

Six patients presented nosocomial pneumonia. The time between the start of mechanical ventilation and nosocomial pneumonia was a median 40.5 (IQR 13-53) days. Pseudomonas aeruginosa $(n=4)$, Enterococcus faecalis $(n=1)$, and Klebsiella pneumoniae $(n=1)$ were isolated from bacteriological cultures of respiratory tract samples.

Length of stay in the ICU was a median 18 (IQR 2-77) days. Seven patients died in the ICU. The causes of death were septic shock with multiorgan failure $(n=5)$, refractory cardiogenic shock $(n=1)$, and refractory hypoxemia $(n=1)$.

\section{Discussion}

Pulmonary TB is an unusual cause of ARDS in France. At the hospital in Montpellier, we found less than 1 case per year. Zahar et al. described 22 cases of ARDS and TB that occurred in 2 ICUs over the course of 7 y in Paris [5]. A septic haemodynamic profile due to $\mathrm{TB}$ in the absence of co-infection has rarely been described [8]; lipoarabinomannan present in the mycobacterial wall could act as a sepsis promoter [9]. 
In our study, the mortality rate was near $90 \%$. This ICU mortality rate is very high, especially as all patients were HIV-negative and all isolates of $M$. tuberculosis were susceptible to first-line anti-tuberculous drugs. Global ARDS mortality has been determined to be $40 \%$ [10]. Previous studies have established the TB-ARDS mortality rate to be $60 \%$ $[2,3]$ and have identified factors of a poor prognosis to include: multiple organ failure, low $\mathrm{PaO}_{2} / \mathrm{FiO}_{2}$ ratio, low serum albumin, and delay of initiation of ATT [3-5]. In our study, 7/8 patients had multiple organ failure, $5 / 8$ had undernutrition, and the delay between onset of symptoms and ATT was a median 46 (IQR 15-124) days. These factors associated with a high incidence of nosocomial pneumonia probably explain the high mortality found in our study.

Nosocomial pneumonia was present in $6 / 8$ patients and $\mathrm{P}$. aeruginosa was the most commonly identified pathogen. In other studies of TB and ARDS, there has been no information about nosocomial pneumonia under mechanical ventilation. There is probably a particular interest in preventing mechanical acquired pneumonia in ARDS TB patients [1].

We acknowledge limitations to our study; it was limited to a single university hospital with a relatively small sample size and was retrospective in design. This may have led to various biases.

In conclusion, pulmonary $\mathrm{TB}$ can lead to ARDS, a rare but specific condition, and is associated with high ICU mortality. A septic haemodynamic profile requiring vasopressors can be present without coinfections. Factors of a poor prognosis found in our study were multiple organ failure, low $\mathrm{PaO}_{2} / \mathrm{FiO}_{2}$ ratio, low serum albumin, and a delay in initiation of ATT. Nosocomial mechanical acquired pneumonia was not rare and in our view needs to be the target of prevention strategies and needs to be treated promptly.
Declaration of interest: The authors report no conflict of interest. The authors alone are responsible for the content and writing of the paper.

\section{References}

[1] Lin SM, Wang TY, Liu WT, Chang CC, Lin HC, Liu CY, et al. Predictive factors for mortality among non HIV-infected patients with pulmonary tuberculosis and respiratory failure. Int J Tuberc Lung Dis 2009;13:335-40.

[2] Ryu YJ, Koh WJ, Kang EH, Suh GY, Chung MP, Kim H, et al. Prognostic factors in pulmonary tuberculosis requiring mechanical ventilation for acute respiratory failure. Respirology 2007; 12:406-11.

[3] Lee PL, Jerng JS, Chang YL, Chen CF, Hsueh PR, Yu CJ et al. Patient mortality of active pulmonary tuberculosis requiring mechanical ventilation. Eur Respir J 2003;22:141-7.

[4] Sharma SK, Mohan A, Banga A, Saha PK, Guntupalii KK. Predictors of development and outcome in patients with acute respiratory distress syndrome due to tuberculosis. Int J Tuberc Lung Dis 2006;10:429-35.

[5] Zahar JR, Azoulay E, Klement E, De Lassence A, Lucet JC, Regnier B, et al. Delayed treatment contributes to mortality in ICU patients with severe active pulmonary tuberculosis and acute respiratory failure. Intensive Care Med 2001;27:513-20.

[6] Bernard GR, Artigas A, Brigham KL, Carlet J, Falke K, Hudson L, et al. Report of the American-European Consensus conference on ARDS: definitions, mechanisms, relevant outcomes and clinical trial coordination. The Consensus Committee. Intensive Care Med 1994;20:225-32.

[7] Frieden TR, Sterling T, Pablos-Mendez A, Kilburn JO, Cauthen GM, Dooley SW. The emergence of drug-resistant tuberculosis in New York City. N Engl J Med 1993;328: 521-6.

[8] Ahula SS, Ajuha SK, Phelps KR, Thelmo W, Hill AR. Hemodynamic confirmation of septic shock in disseminated tuberculosis. Crit Care Med 1992;20:901-3.

[9] Shinnick TM, King HC, Quinn FD. Molecular biology, virulence and pathogenicity of mycobacteria. Am J Med Sci 1995;309:92-8.

[10] Brun-Buisson C, Minelli C, Bertolini G, Brazzi L, Pimentel J, Lewandowski K, et al. Epidemiology and outcomes of acute lung injury in European intensive care units. Results from the ALIVE study. Intensive Care Med 2004;30:51-61. 